\title{
Cutaneous Graft-versus-Host Disease: A Guide for the Dermatologist
}

\author{
Peter Häusermann ${ }^{a}$ Roland B. Walter ${ }^{\mathrm{e}}$ Jörg Halter ${ }^{c}$ Barbara C. Biedermann ${ }^{\mathrm{b}, \mathrm{d}}$ \\ André Tichellic Peter Itin ${ }^{\mathrm{c}}$ Alois Gratwohlc \\ Departments of ${ }^{a}$ Dermatology and ${ }^{b}$ Research and ${ }^{c}$ Division of Hematology, University Hospital Basel, and

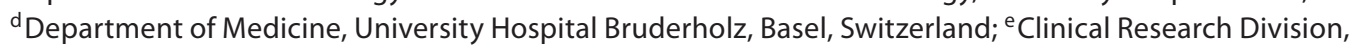 \\ Fred Hutchinson Cancer Research Center, Seattle, Wash., USA
}

\author{
Key Words \\ Graft-versus-host disease, cutaneous $\cdot$ Hematopoietic \\ stem cell transplantation · Lichenoid dermatitis • \\ Dermatopathology
}

this disease focused for the dermatologist, and additionally it emphasizes the recent consensus documents on the various aspects of chronic GVHD of the National Institute of Health.

Copyright $\odot 2008$ S. Karger AG, Basel

\begin{abstract}
Graft-versus-host disease (GVHD) is defined by the aggregation of clinical and pathological manifestations in a recipient of allogeneic stem cells or bone marrow transplantation in which specific immunological as well as nonspecific phenomena lead to characteristic features. GVHD is one of the major complications after hematopoietic stem cell transplantations and responsible for posttherapeutic morbidity, mortality and decrease in quality of life of those patients. GVHD is critically induced and maintained by donor immunocompetent cells that particularly attack epithelia of fast proliferating tissues such as those from the liver, gastrointestinal tract and skin. On the basis of the time of presentation, cutaneous GVHD has been originally divided into an acute and chronic disease. The latter has traditionally been further subclassified into a more epithelial or lichenoid and a predominantly dermal or sclerodermoid form. With respect to the growing importance of this therapeutic procedure and increasing numbers of outpatients presenting with chronic GVHD, this article summarizes the updated knowledge on
\end{abstract}

\section{KARGER \\ Fax +41613061234 \\ E-Mail karger@karger.ch}

www.karger.com

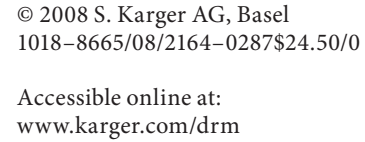

\section{Evolution of Hematopoietic Cell Transplantation}

Hematopoietic stem cell transplantation (HSCT) in its current form evolved over the last 50 years from research initially aimed at treating the sequelae of radiation exposure that were feared in the 'Cold War' and Nuclear Age era [1]. Pioneering studies showed that lethally irradiated mice could survive radiation-induced bone marrow aplasia if the spleen was shielded by a lead foil or, later, after transfusion of bone marrow from mice of the same strain [2-5]. After it had initially been debated whether the protective effect was due to 'a substance of noncellular nature' (humoral hypothesis) or transplanted cells (cellular hypothesis), several laboratories subsequently used cytogenetic markers to unequivocally demonstrate that the radioprotective effect of bone marrow transplantation resulted from the replacement of the damaged hematopoietic system of the host by healthy cells from the donor [6]. These early animal studies formed the rational basis for

Dr. Peter Häusermann

Department of Dermatology, University Hospital Basel

Petersgraben 4

CH-4031 Basel (Switzerland)

Tel. +41 6126525 25, Fax +41 6126548 85, E-Mail phaeusermann@uhbs.ch 
the first attempts to treat human leukemias with highdose chemoradiotherapy followed by syngeneic or allogeneic (for glossary, see table 1) bone marrow transplantation, and clinical investigators on both sides of the Atlantic Ocean soon communicated their initial promising results. For example, George Mathé published the successful use of allogeneic marrow infusions to rescue victims of accidental irradiation exposure in Europe some years later than E. Donnell Thomas from the USA, who was awarded the Nobel Prize in Physiology or Medicine together with Joseph E. Murray in 1990 for groundbreaking work on organ and cell transplantation in the treatment of human disease [7, 8]. Final proof of concept came with the first successful bone marrow transplantation from a human leukocyte antigen (HLA)-mismatched sibling donor followed by several HLA-identical sibling transplantations in children with severe combined immunodeficiency in 1968 [9].

Over the last decades, allogeneic HSCT has become an important therapeutic modality not only for the treatment of hematological malignancies (e.g. leukemias or lymphomas), but also for the treatment of nonmalignant hematological stem cell disorders (e.g. severe aplastic anemia), genetic diseases (e.g. severe combined immunodeficiency or thalassemia) and, under certain conditions, even solid tumors (e.g. renal cell cancer) [10-13]. The growing importance of HSCT is emphasized by an ongoing increase in its use over the last 20 years [14]. Today, transplanted stem cells are used from autologous, syngeneic and allogeneic sources and are collected from bone marrow, peripheral blood after mobilization or umbilical cord blood. Moreover, allogeneic HSCT is increasingly performed with success over HLA barriers due to limited numbers of HLA-matched siblings, e.g. from parents (haploidentical), HLA-mismatched siblings, and matched or mismatched unrelated donors. What has been a highly experimental therapy only a few decades ago has now emerged as standard of care for many diseases [11, 15].

Currently, the main limitations of allogeneic HSCT include treatment-related toxicity, relapse of the underlying disease (in the setting of malignant stem cell disorders) and immunological complications such as rejection, graft-versus-host disease (GVHD) and delayed immune reconstitution. GVHD in its acute or chronic form is the main cause of nonrelapse morbidity and mortality both as a direct complication (e.g. bronchiolitis obliterans) or via associated immunodeficiency and susceptibility to severe infections $[16,17]$. With the increasing number of patients undergoing HSCT and the more widespread use of mismatched transplantation, the der- matologist will be more and more confronted with GVHD in her/his daily practice, and it is thus the goal of the current article to provide a concise overview of the pathomechanisms underlying GVHD, changing disease concepts, and main clinical and pathological features with focus on the skin, as well as to summarize and discuss recently published consensus documents from the National Institute of Health (NIH) on various aspects of chronic GVHD [18-25]. While some general therapeutic considerations are presented in the final chapter, an exhaustive discussion of current treatment modalities or prophylaxis of acute and chronic GVHD is beyond the scope of this article, and the interested reader is referred to recent reviews concerning these topics [26-28].

\section{Basic Requirements of GVHD}

GVHD reflects an interaction between the donor and recipient that was first described in animals by Rupert $\mathrm{E}$. Billingham, who observed that mice from genetically disparate but not syngeneic donors developed a secondary lethal disease characterized by wasting, diarrhea and skin lesions following recovery from radiation-induced aplasia [29]. He realized the similarity of this 'wasting disease' with other poorly understood phenomena such as 'runt disease' in newborn mice injected with allogeneic spleen cells, the ' $\mathrm{F}_{1}$ hybrid disease' or the 'parabiosis intoxication' [29]. In 1966, he proposed the requirements under which GVHD can occur: first, the transplanted graft must contain immunologically competent cells; second, the recipient must express tissue antigens that are not present in the transplant donor and thus can be recognized as foreign; third, the recipient must be incapable of rejecting the transplanted cells [30]. These propositions held true over time, and it is nowadays recognized that the mediators of GVHD are mature T cells that clonally expand in an antigen-specific manner after recognition of nonself HLAs expressed on the cell surface of nucleated cells in the host that is chemically or physiologically immunocompromised [31, 32].

\section{The Increasing Significance of Chronic GVHD for the Dermatologist}

Contrary to some expectations, the incidence of GVHD did not significantly decrease over the last 20 years and still develops in about half of all patients undergoing allogeneic HSCT [33]. While novel transplanta- 
Table 1. Glossary

\begin{tabular}{ll}
\hline Technical term & Description \\
\hline Hematopoietic cell transplantation & $\begin{array}{l}\text { Superior term for transfer of hematopoietic cells within one individual or from one individual to } \\
\text { another } \\
\text { Process of infusing healthy hematopoietic stem cells into patients who have undergone previous } \\
\text { chemo- or radiotherapy mainly for hematological disorders; stem cells are infused into the venous } \\
\text { bloodstream from where they move to the bone marrow and form new blood cells }\end{array}$ \\
Depending on donor type, 3 types of stem cell transplants can be distinguished: autologous, \\
allogeneic and syngeneic; depending on the site and mode of harvest, 3 different types of HSCT can \\
be distinguished: BMT, PBSCT, CBT \\
Stem cell sources \\
anesthesia
\end{tabular}

\section{Donor type}

Autologous transplantation

Syngeneic transplantation

Allogeneic transplantation

The patient's own cells are used for HSCT

The cells of a twin are used for HSCT

The cells from another person are used as stem cell source (bone marrow, peripheral blood, cord blood), either from the same family or from an unrelated donor

HLA-identical sibling

HLA (MHC)-matched cells from sibling

HLA-identical other family member

Non-HLA-identical family member

Unrelated donor

Xenogeneic

HLA (MHC)-matched cells from another family member

HLA (MHC)-mismatched cells from a family member

HLA (MHC)-matched or -mismatched cells from an unrelated donor

HCT from one species (e.g. human) to another (nonhuman)

Matching criteria

Matched related/unrelated donor

Mismatched related/unrelated donor

Genotypically identical

HLA compatibility between donor and recipient (only in terms of HLA antigens)

HLA incompatibility between donor and recipient (only in terms of HLA antigens)

The same two haplotypes have been inherited by the donor and the recipient from the same parental chromosomes (siblings with the same parents)

Phenotypically identical

Both haplotypes are identical in the donor and the recipient but they are not inherited from the same parental chromosomes (unrelated donors are by definition at best phenotypically identical)

$6 / 6,10 / 10,12 / 12$ Degree of match between 6,10 or 12 HLA antigens

MHC antigens; identical with

HLA antigens

Molecules that are expressed by all nucleated cells (MHC class I) or by a subset of hematopoietic cells and thymic stroma cells (MHC class II) which are recognized by CD8+ T cells (MHC I) or predominantly by CD4+ T cells (MHC II)

Minor histocompatibility antigens

Peptides derived from polymorphic intracellular proteins that are presented on the cell membrane in the context of HLA class I or II molecules and that can be recognized as alloantigens by T cells of an HLA-matched/identical individual; they have a role for the GVHD and GVT effect

Conditioning regimens

Myeloablative conditioning (traditional) regimen

Reduced-intensity conditioning

Pretransplantation treatment with chemoradiotherapy to reduce tumor burden and lower immunoreactivity of the host in order to allow engraftment of the transplant

Primary targets are the elimination of the tumor cells as well as induction of a state of immunosuppression in the host that allows the transplantation

The primary target is to induce a state of immunosuppression in the host to allow transplantation; elimination of the recipient stem cells as well as of residual tumor cells is mainly performed by immunocompetent donor cells

\section{GVHD} Immunocompetent donor cells react against tissues of the recipient

GVT reaction/effect

Immunocompetent donor cells react against malignant tumor cells of the host

$\mathrm{BMT}=$ Bone marrow transplantation; PBSCT $=$ peripheral blood stem cell transplantation; $\mathrm{CBT}=$ cord blood transplantation; $\mathrm{G}-\mathrm{CSF}=$ granulocyte colony-stimulating factor; HLA = human leukocyte antigen; $\mathrm{MHC}=$ major histocompatibility complex; HCT = hematopoietic cell transplantation; GVHD = graft-versus-host disease; GVT = graft-versus-tumor. 
Table 2. Factors predisposing recipients of allogeneic HSCT to the development of GVHD (adapted from Schaffer [34])

\begin{tabular}{|c|c|c|c|c|}
\hline Main characteristics influencing the occurrence and severity of GVHD & $\begin{array}{l}\text { Risk for } \\
\text { acute GVHD }\end{array}$ & $\begin{array}{l}\text { Severity of } \\
\text { acute GVHD }\end{array}$ & $\begin{array}{l}\text { Risk for } \\
\text { chronic GVHD }\end{array}$ & $\begin{array}{l}\text { Severity of } \\
\text { chronic GVHD }\end{array}$ \\
\hline \multicolumn{5}{|l|}{ Characteristics of the donor and recipient } \\
\hline HLA disparity & $\uparrow$ & $\uparrow$ & $\uparrow$ & $\uparrow$ \\
\hline \multicolumn{5}{|l|}{ Unrelated HLA-matched donor } \\
\hline (mismatched minor histocompatibility antigens) & $\uparrow$ & $\uparrow$ & $\uparrow$ & $\uparrow$ \\
\hline Female $(\mathrm{XX})$ donor to male $(\mathrm{XY})$ recipient & $\uparrow$ & $\uparrow$ & $\uparrow$ & $\uparrow$ \\
\hline Older age of donor or recipient & $\uparrow$ & $?$ & $\uparrow$ & $?$ \\
\hline Prior acute GVHD & - & - & $\uparrow$ & $?$ \\
\hline \multicolumn{5}{|l|}{ Characteristics of the transplantation protocol } \\
\hline vs. reduced-intensity ('mini') conditioning regimens) & $=$ & $\uparrow ?$ & $\uparrow$ & ? \\
\hline \multicolumn{5}{|l|}{ G-CSF-mobilized peripheral blood rich in CD34+ cells } \\
\hline (source and dose of hematopoietic stem cells) & $\uparrow$ & $\uparrow$ & $\uparrow$ & ? \\
\hline Unmodified (T-cell-replete) graft & $\uparrow$ & $\uparrow$ & $\uparrow$ & $?$ \\
\hline \multicolumn{5}{|l|}{ Less aggressive administration of prophylactic } \\
\hline immunosuppressive agents (to prevent GVHD) & $\uparrow$ & $\uparrow$ & $\uparrow$ & $?$ \\
\hline \multicolumn{5}{|l|}{ T cell depletion (no GVT effect and high probability for } \\
\hline early relapse in case of malignancy and severe infections) & $\downarrow$ & $\downarrow$ & $\downarrow$ & $\downarrow$ \\
\hline \multicolumn{5}{|c|}{ Later interventions (may be intended to incite a graft-versus-malignancy effect) } \\
\hline Withdrawal of immunosuppressive drugs & $\uparrow$ & $?$ & $\uparrow$ & $\uparrow ?$ \\
\hline Donor T lymphocyte infusions & $\uparrow$ & $?$ & $\uparrow$ & $\uparrow ?$ \\
\hline
\end{tabular}

G-CSF = Granulocyte colony-stimulating factor; GVT = graft-versus-tumor; $\uparrow=$ increased risk/severity of GVHD; $\downarrow=$ decreased risk/severity of GVHD; = = equal risk/severity of GVHD; ? = unclear effect on GVHD.

tion techniques such as reduced-intensity conditioning regimens are associated with less severe acute GVHD relative to myeloablative regimens, the incidence of acute GVHD has remained unchanged (table 2) [33, 35]. By comparison, extended eligibility criteria for patients undergoing transplantation (e.g. increased upper age limit), increased HLA disparity, prolonged initial survival due to reduction of early mortality as a consequence of better prophylaxis and treatment strategies of immediate complications of transplantation (e.g. acute GVHD and infections), and increased use of peripheral blood stem cells have increased the risk for chronic GVHD [36].

The role of the dermatologists is limited in acute GVHD and mainly lies in the precise assessment of cutaneous involvement and the exclusion of other skin pathologies. In contrast, the dermatologist needs to be increasingly aware of the manyfold faces and long-term problems associated with chronic GVHD. Sustained involvement of the skin, including mucosal and adnexal sites, is common in chronic GVHD, and dermatologists have to play an active role in the long-term outpatient management and treatment of that disease, in particular because persistent cutaneous lesions are pivotal for morbidity and quality of life (QOL) of those patients [37, 38]. Furthermore, dermatologists will appropriately be obliged to have a central role in the continuous monitoring of treatment responses throughout the disease course over long periods of time based on their professional specification. The rising significance of chronic GVHD is reflected by the recent implementation of an NIH Consensus Development Project on Criteria for Clinical Trials in Chronic GVHD. Six working groups provided consensus statements for diagnosis and staging, pathology, biomarkers, response criteria, ancillary therapy and supportive care, and design of clinical trials in chronic GVHD [20-25]. These consensus documents summarize the current international standard criteria for diagnosis and activity assessment and provide guidance in the organ and overall scoring as well as treatment of chronic GVHD; their implications for the dermatologist will be discussed in later sections of this article. 


\section{Basic Mechanisms of Acute and Chronic GVHD}

The molecular mechanisms underlying acute GVHD are much better investigated and understood than the pathogenesis of the chronic disease. Of particular note, it is still a matter of debate whether acute and chronic GVHD represent two different phases of the same disease or two independent diseases, both related to allogeneic HSCT but associated with different molecular and pathophysiological mechanisms [39]. Figure 1 illustrates the current model that includes aspects of classic alloreactivity, autoimmunity and immunodeficiency, phenomena that occur in various intensities in acute and chronic GVHD. The skin has been used in basic, animal and clinical research as a model organ for GVHD since the very beginning, which has led to a fairly good understanding of some aspects of that disease [40,41]. Figure 2 outlines the main principles of acute GVHD in a simplified 3-step process $[42,43]$. Conditioning regimens such as total body irradiation result in initial toxic epithelial injuries of highly proliferating organs such as the gut, liver and skin, thereby causing a cell-damage-induced proinflammatory cytokine milieu. These events in turn activate keratinocytes, dermal dendritic and particularly antigenpresenting epidermal dendritic Langerhans cells as well as antigen-presenting cells of the gut and liver, with ensuing increased expression of several cell surface proteins. Pivotal among these are major-histocompatibility-complex-related gene products (including HLA antigens) which also present minor histocompatibility antigens (miHA) [43-45]. The enhanced expression of HLA antigens by activated host antigen-presenting cells then activate donor $\mathrm{T}$ cells to increase the secretion of Th1 cytokines such as IFN- $\gamma$, IL-2 and TNF- $\alpha$, eventually leading to the expansion of antigen-specific alloreactive $\mathrm{T}$ cells. These events are followed by the generation of cytotoxic and inflammatory cytokines, cytotoxic effector cells that dispose of Fas- and perforin-mediated killing mechanisms, large granular lymphocytes and nitric oxide. Ultimately, epithelial cell apoptosis, cell death and tissue damage are induced by the orchestrated interaction of alloreactive donor $\mathrm{T}$ cells, inflammatory cytokines and cells of the innate immune system (large granular lymphocytes, natural killer cells) [43, 46]. It is important to realize that even in the absence of an HLA mismatch between the donor and recipient, cutaneous GVHD can develop in the setting of miHA mismatching, as evidenced by human skin explant assays using minor-antigen-specific cytotoxic T cells (CTLs) [47]. Finally, it has been shown that isolated cutaneous GVHD can occur in skin expressing ubiquitous minor antigens $(\mathrm{H}-\mathrm{Y})$ that were recognized by their respective CTLs, but not in the setting of hematopoietic restricted miHA-specific CTLs (HA-1, HA-2) that did not attack the skin. The role of miHA in the setting of allogeneic transplantation is best exemplified by the increased incidence and severity of GVHD in male recipients of female grafts [48].

Attention has recently been drawn to the role of regulatory $\mathrm{T}$ cells $\left(\mathrm{T}_{\text {reg }}\right)$ in acute GVHD. Naturally occurring $\mathrm{CD} 4+\mathrm{CD} 25+\mathrm{T}_{\text {reg }}$ cells, which are phenotypically best characterized by their FoxP3 expression (the forkhead/ winged helix transcription factor gene that is specifically required for their thymic development), have been shown to occur at a lower frequency in the peripheral blood of patients with acute GVHD compared to patients without GVHD, an observation that may suggest their potential benefit in the prevention and treatment of that disease. More specifically, naturally occurring thymus-derived $\mathrm{CD} 4+\mathrm{CD} 25+\mathrm{FoxP} 3+\mathrm{T}_{\text {reg }}$ cells are currently investigated for their potential to induce and maintain tolerance to allo- (and self-)antigens and to suppress allo(and auto-)reactivity [49].

Similar to acute GVHD, chronic GVHD is also thought to be an immune-mediated process that mostly involves alloreactive cells, with donor-derived CD4+ and CD8+ T cells as main effectors [50]. As a hallmark feature, the chronic disease may present with clinical and laboratory findings that resemble various autoimmune disorders, e.g. bronchiolitis obliterans, Sjögren's syndrome, immune cytopenias and cutaneous sclerosis, suggesting that dysfunctional humoral immunity might be involved in the pathogenesis as well [51-53]. Indeed, a high prevalence of autoantibodies against a variety of antigens has been observed in these patients and is thought to be the result of autoreactive CD4+ T cells that arose in the setting of an injured thymus with impaired negative selection [54]. In contrast to acute GVHD, however, it has been suggested that chronic GVHD is primarily a Th2-type immune-mediated disease, as evidenced by increased levels of IL-4, IL-5, eosinophils and elevated expression of transforming growth factor $\beta$ in lesional sclerodermoid skin [55, 56]. In addition, Biedermann et al. [57] hypothesized that CTL-mediated endothelial injury and subsequent loss of dermal vessels with impaired blood perfusion could be contributory to tissue fibrosis. The shift from an initially Th1-mediated acute disease to a predominantly Th2-mediated chronic immune disease has recently been evidenced in a murine sclerodermoid model by sequential global gene expression analysis. Cytokine messenger RNAs for profibrotic growth factors, 
Fig. 1. The current concept of GVHD adapted from http://ccr.cancer.gov/resources/gvhd/about.asp. GI = Gastrointestinal; GU = genitourinary.

Fig. 2. Three-step model of the pathophysiology of acute cutaneous GVHD. DC = Dendritic cell; $\mathrm{Ag}=$ antigen; $\mathrm{MHC}=$ major histocompatibility complex; $\mathrm{TCR}=\mathrm{T}$ cell receptor. Phase 1: the conditioning regimen results in keratinocyte injury within a proinflammatory milieu (e.g. TNF- $\alpha$, IL-1) that induces antigen-presenting dendritic cells to express costimulatory molecules (e.g. CD80/86, CD40) and increased cell surface levels of major histocompatibility class I and II molecules. Phase 2: after allogeneic HSCT, antigen presentation by host dendritic cells leads to activation of donor T cells and production of Th1 cytokines (e.g. IFN- $\gamma$, IL-2). Phase 3: donor cytotoxic T cells mediate direct keratinocyte necrosis/apoptosis (by using e.g. perforins and granzymes) together with cytokines (e.g. TNF- $\alpha$ ) and other cells of the innate immune system (for details, see text).

\section{Changing concepts: GVHD syndrome after allo-HCT}

Acute GVHD: rash, GI, liver Chronic GVHD: skin, eyes, mouth, GI, liver, musculoskeletal, lungs, GU

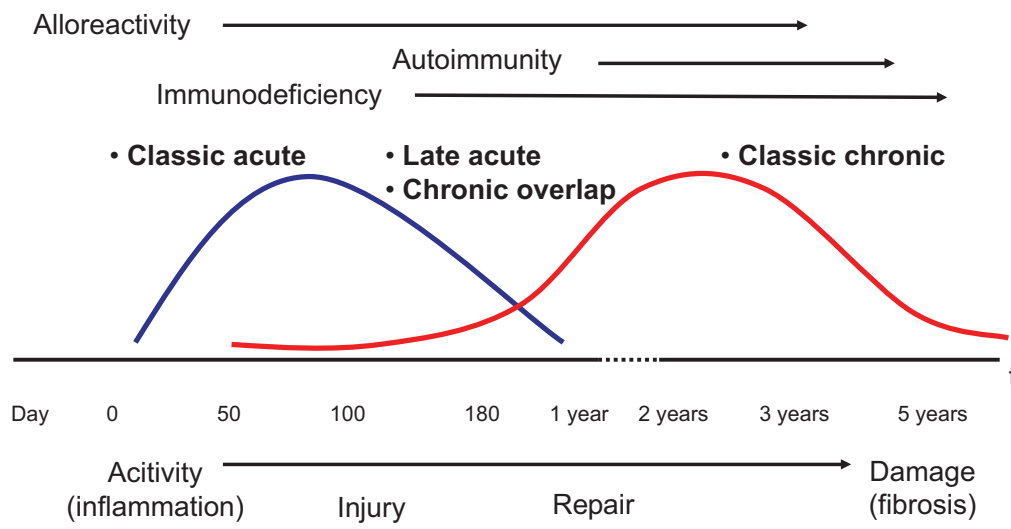

Phase 1: effects of HSCT conditioning

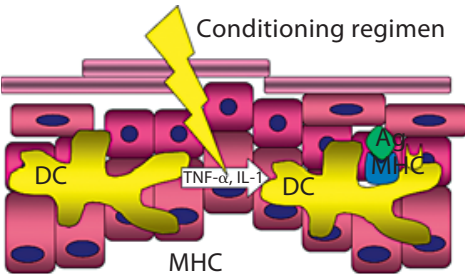

Y Secondary signal

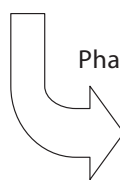

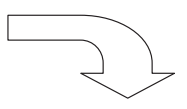

Phase 2: donor T cell activation
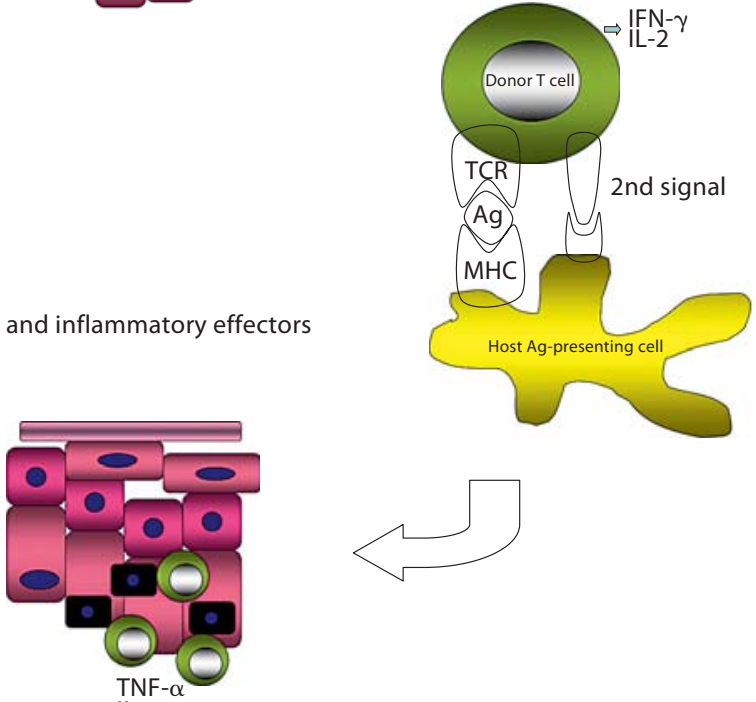

- Keratinocyte necrosis and apoptosis of recipient

(2) Donor cytotoxic T cells 
such as platelet-derived growth factor c, connective tissue growth factor or fibroblast growth factor, have been shown to be elevated similar to human scleroderma [41]. However, platelet-derived growth factor receptor antibodies stimulating type I collagen gene expression and myofibroblast phenotype conversion in normal human primary fibroblasts that have been found in patients with systemic sclerosis are not yet known in fibrosing variants of chronic cutaneous GVHD [58].

Similar to the acute counterpart, there is an increasing scientific interest in the potential role of $\mathrm{T}_{\text {reg }}$ cells in chronic GVHD [59]. However, their ability to influence chronic GVHD remains elusive. So far, it potentially turns out that the dysbalance between regulatory (tolerogenic) cells and alloreactive effector cells will enhance the risk of onset and persistence of chronic GVHD [60, 61]. Finally, there is also evidence that B cells can contribute to the development of GVHD, predominantly in its chronic form, particularly in male patients with transplants from female donors while conversely host B cells may also have the potential to attenuate GVHD by secreting IL-10 [62, 63].

\section{Clinical Manifestations of Cutaneous GVHD}

Clinically, GVHD presents either as an acute disease within days to weeks after allogeneic HSCT mainly during the inpatient phase or, alternatively, as a more heterogeneous chronic syndrome that usually occurs months to years after discharge from the hospital. Most challenging with respect to the potential differential diagnosis (e.g. viral infections, drug reactions) is a skin rash that usually occurs within the first 10-14 days after transplantation at the time of marrow engraftment but before the appearance of peripheral lymphocytes. Some authorities term this poorly characterized eruption that often occurs in the setting of multiple HLA mismatched antigens 'hyperacute type of acute GVHD' or 'early mismatch GVHD' which is generally characterized by an erythematous maculopapular eruption that occasionally becomes generalized, and is associated with high fever, hepatitis and intestinal symptoms. It remains open whether the socalled engraftment syndrome in autologous HSCT particularly following the administration of cyclosporine represents a similar phenomenon or not $[64,65]$. Typically, however, acute GVHD develops between day 14 and day 42 after transplantation; the timing depends on the conditioning regimen, with a peak incidence around day 30 after myeloablative transplantation and most often later in the setting of reduced-intensity nonmyeloablative regimens or delayed engraftment of umbilical cord bloodderived stem cells. The skin can be the only target organ in acute GVHD or is often attacked before the liver and/ or gastrointestinal tract. The spectrum of skin lesions after traditional conditioning regimens was recognized over 30 years ago and has been reviewed for the dermatologist previously [66,67]; these cutaneous features are still considered the most prominent characteristics of the disease. Usually, a symmetrical morbilliform or maculopapular rash with a rather sudden onset is found that predominantly involves the upper back and lateral neck but is sometimes accentuated on the palms, soles, pinnae and cheeks (fig. 3). The eruption may begin acrally but eventually shows a generalized distribution. Prominent acral erythema, a violaceous discoloration of the pinnae and folliculocentric blanching erythema with tiny macules and small papules can be suggestive of that disease. In severer cases, the exanthema can progress to a diffuse erythroderma with bulla formation, a positive Nikolsky sign and desquamation that resembles drug-induced toxic epidermal necrolysis. The mucous membranes and particularly the conjunctivae can be involved as well, and the former can be difficult to differentiate from conditioning-related mucositis $[68,69]$. The skin involvement in acute GVHD is measured according to the extent of the lesions (stage $1=25 \%$ of body surface area; stage $2=$ $25-50 \%$; stage $3=50 \%$ up to erythroderma; stage $4=$ erythroderma with bullae) and is included, besides liver and gastrointestinal symptoms/disease, in the prognostically relevant overall grading of acute GVHD (table 3). Approximately half of the patients with moderate to severe GVHD (grades 2-4) may die as a consequence of this treatment-related toxicity $[46,68]$.

Early lesions of chronic GVHD are often subtle and may include dryness of skin (xerosis), follicular prominence (keratosis-pilaris-like lesions), ichthyosis and papulosquamous lesions [68]. Psoriasiform and pityriasis-rosea-like skin changes as well as annular lesions resembling annular psoriasis, the superficial type of erythema annulare centrifugum or subacute cutaneous lupus erythematosus may be present before the more classical presentations develop, namely lichen-planus-like and sclerodermoid changes (fig. 4) [19]. Lichenoid lesions are characterized by erythematous or violaceous lichenoid papules and plaques that usually affect the dorsal aspects of the hands, forearms and trunk. They may show folliculotropism, rarely follow Blaschko's lines or appear in the dermatomal site of a previous herpes zoster infection [72]. Sclerodermoid chronic GVHD often presents with plaques 

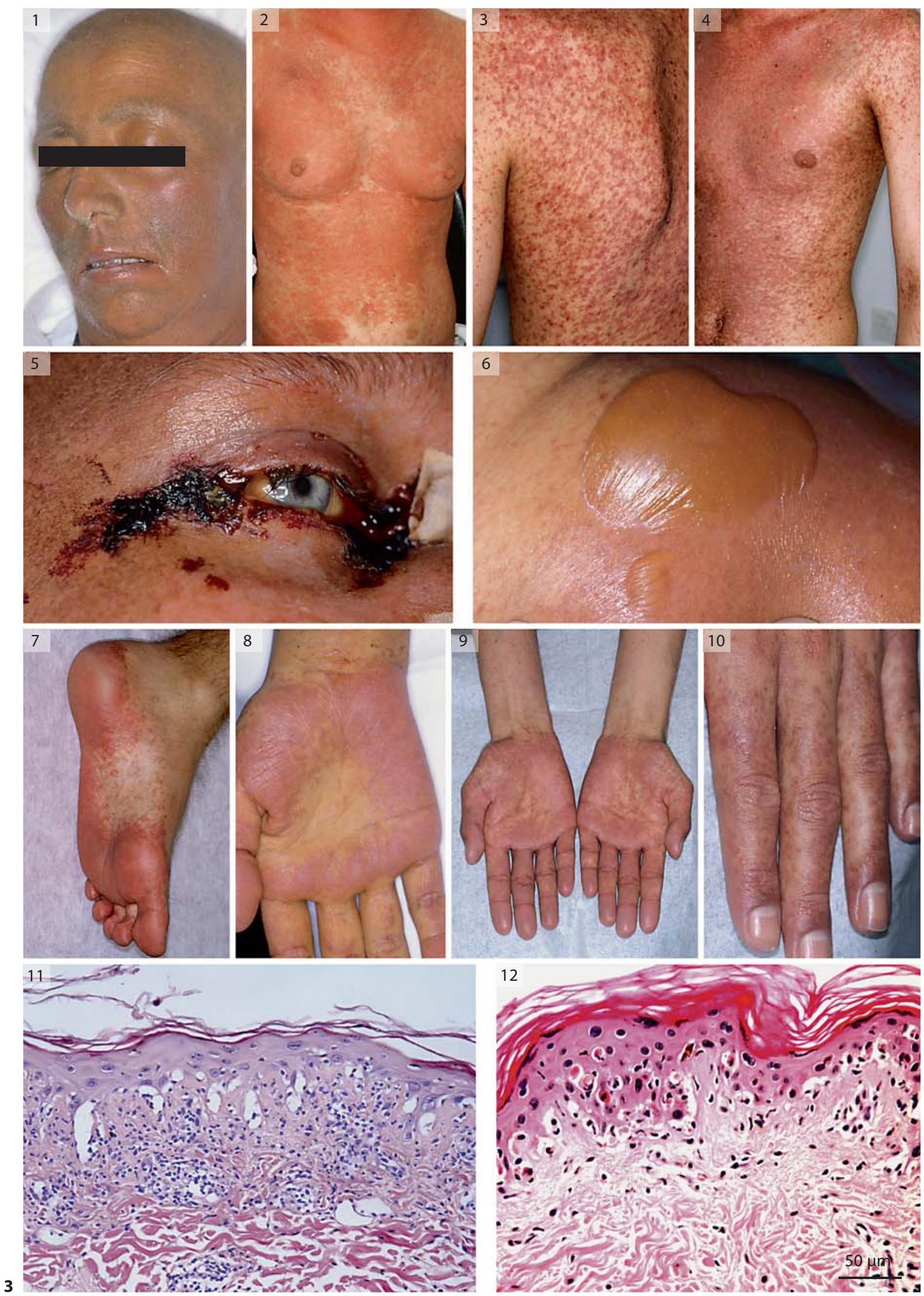
Table 3. Consensus grading and organ extent of involvement of acute GHVD (adapted from Antin and Deeg [70] and Przepiorka et al. [71])

\begin{tabular}{|c|c|c|c|}
\hline & Skin & Liver & Intestinal tract \\
\hline \multicolumn{4}{|l|}{ Stage } \\
\hline 1 & rash on $<25 \%$ of skin & bilirubin $2-3 \mathrm{mg} / \mathrm{dl}$ & diarrhea $>500 \mathrm{ml} /$ day or persistent nausea \\
\hline 2 & rash on $25-50 \%$ of skin & bilirubin $3-6 \mathrm{mg} / \mathrm{dl}$ & diarrhea $>1,000 \mathrm{ml} /$ day \\
\hline 3 & rash on $>50 \%$ of skin & bilirubin $6-15 \mathrm{mg} / \mathrm{dl}$ & diarrhea $>1,500 \mathrm{ml} /$ day \\
\hline 4 & erythroderma with bulla formation & bilirubin $>15$ mg/dl & severe abdominal pain with or without ileus \\
\hline \multicolumn{4}{|l|}{ Grade } \\
\hline 0 & none & none & none \\
\hline I & stage $1-2$ & none & none \\
\hline II & stage 3 & or stage 1 & or stage 1 \\
\hline III & - & stage $2-3$ & or stage $2-4$ \\
\hline IV & stage 4 & or stage 4 & - \\
\hline
\end{tabular}

Rash: use the 'rule of nines' to determine body surface area involvement. Bilirubin: range given as total bilirubin; downgrade one stage if an additional cause of elevated bilirubin has been documented. Diarrhea: volume of diarrhea applies to adults; for pediatric patients, the volume of diarrhea should be based on body surface area. Nausea: persistent nausea with histological evidence of GVHD in the stomach or duodenum. Grade IV may also include lesser organ involvement but with extreme decrease in performance status.

of dermal sclerosis that resembles morphea and eventually progresses to generalized scleroderma or, alternatively, presents with lichen-sclerosus-like features in a genital or extragenital distribution. Since its initial recognition, the spectrum of the fibrosing GVHD variants has been continuously extended, and both lichen-sclerosus-type as well as eosinophilic-fasciitis-type sclerotic lesions are now considered diagnostic features and often result in joint contractures [73]. Poikilodermatous changes can be hallmark signs of chronic GVHD and are predominantly observed on the face, lateral neck and trunk, exceptionally in addition to multiple hemangiomas. Adnexal involvement with various nail changes, different types of scarring and nonscarring alopecia, and impairment of sweating are also constant findings, as is involvement of the oral and genital epithelium in up to $80 \%$ of patients [69]. $\mathrm{Mu}-$ cous membrane involvement with dryness, atrophy, hy-

Fig. 3. Hallmark clinical and pathological features of acute mucocutaneous GVHD: acute GVHD with characteristic edematous erythema of the head (panel 1), widespread partly confluent maculopapular rash on the trunk (panels 2-4), severe involvement of the eyes with hemorrhagic crusts (panel 5) and bullous lesions (panel 6) resembling toxic epidermal necrolysis; classical acral lesions with relatively sharp borders (panels 7-10) and prototypical histological changes showing vacuolar interface dermatitis with prominent apoptosis of keratinocytes and so-called satellite necrosis of the basal and suprabasal layer (panels 11, 12). pertrophy, lichenoid changes, lacy white plaques and erosions as well as ulcerative lesions, dental caries and periodontitis/gingivitis can all have a significant impact on nutrition behavior, sexuality and overall QOL [74, 75]. The complete clinical spectrum of skin, adnexal and mucosal involvement in chronic GVHD has recently been reviewed by the NIH Consensus Conference and is outlined in table 4 [20]. One of the most challenging aspects in the diagnosis and management of chronic GVHD is the measurement of disease activity and delineation from nonactive sequelae of a past chronic GVHD. Biedermann et al. [76] proposed a combined assessment of activation markers of circulating $\mathrm{T}$ cells and endothelial injury measured in skin biopsies as a sensitive and specific test to identify patients with active chronic disease.

\section{Impact of Histopathology in the Diagnosis and Prediction of Cutaneous GVHD}

The histological criteria for the diagnosis of acute cutaneous GVHD have been established in 1974 and are still in use today [77]. Basically, acute GVHD reveals the prototypical morphological features of interface dermatitis of the vacuolar type (fig. 3). Damage to the skin epithelium has early been shown to originate in a nonrandom fashion in the tips of the rete ridges exactly at the niche where cytokeratin 15 epidermal cells, presumably epider- 

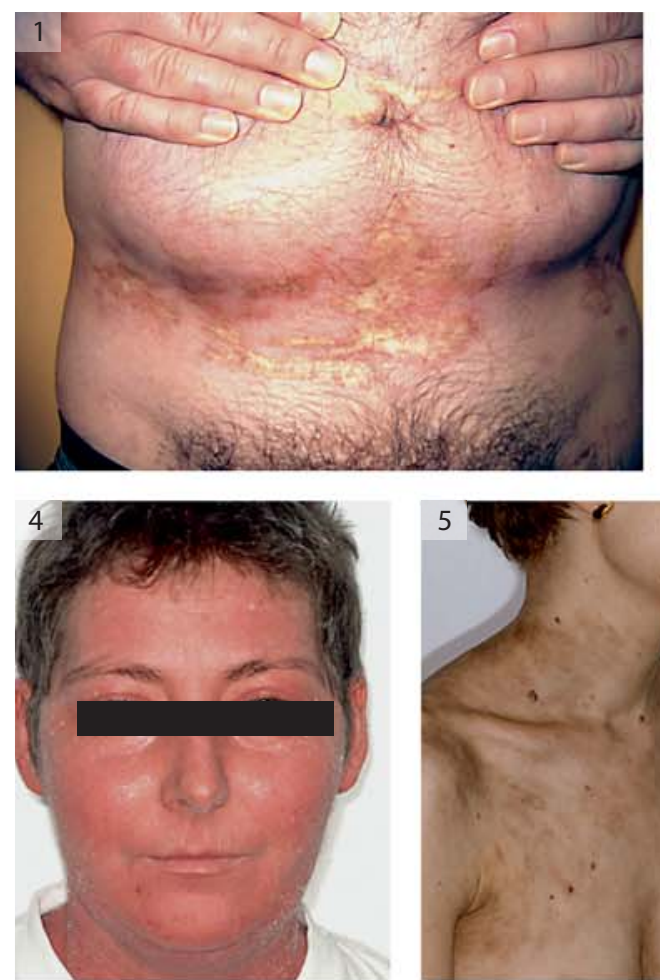

8
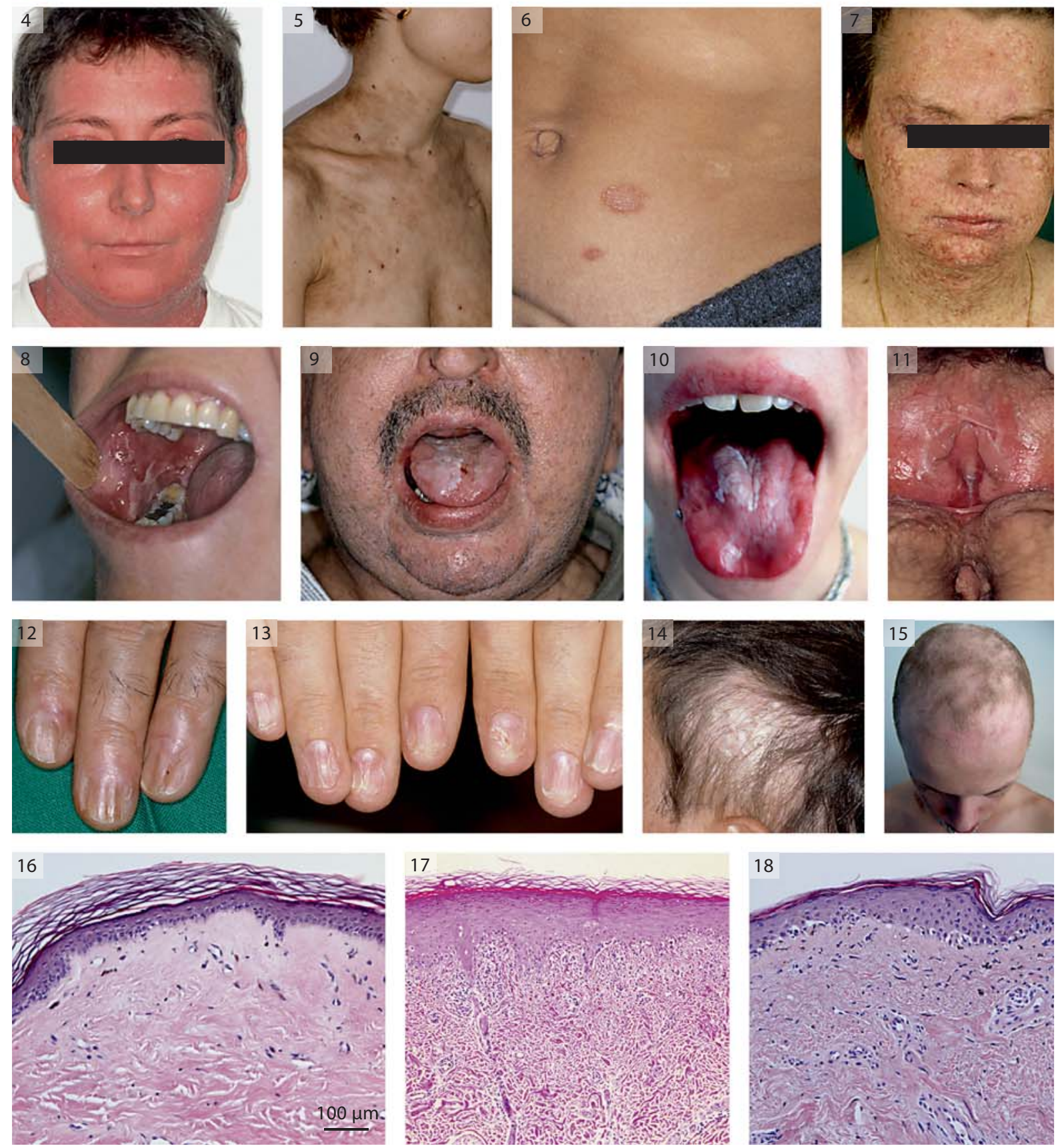
Table 4. Diagnostic criteria for chronic GVHD of the skin, nails, scalp/hairs and mouth (adapted from Filipovich et al. [20])

A diagnosis of chronic GVHD requires

- At least 1 'diagnostic' manifestation or

- At least 1 'distinctive' manifestation plus confirmation of the GVHD diagnosis by biopsy/laboratory tests/imaging in the same or another organ

'Diagnostic' mucocutaneous manifestations

- Lichen-planus-like lesions

- Lichen-sclerosus-like lesions

- Morphea-like lesions

- Sclerotic lesions including deep lesions (eosinophilic fasciitis)

- Poikiloderma

- Oral hyperkeratotic plaques

- Oral lichen-type features

- Restriction of mouth opening due to sclerosis

'Distinctive' mucocutaneous manifestations

- Depigmentation

- New-onset scarring and nonscarring scalp alopecia or papulosquamous lesions or scaling of the scalp

- Nail dystrophy, longitudinal ridging, splitting or brittle features, onycholysis, pterygium unguis and nail loss

- Xerostomia, mucoceles, oral mucosal atrophy, oral ulcers and pseudomembranes

In the absence of clinical or histological signs/symptoms of chronic GVHD, the persistence, recurrence or new onset of characteristic manifestations of acute GVHD should be classified as acute GVHD, regardless of the time after the transplantation.

Fig. 4. Selected spectrum of clinical and pathological lesions in chronic cutaneous GVHD: chronic GVHD with characteristic morphea-like lesions (panel 1), sclerotic features resembling sclerodermia en coup de sabre (panel 2) and eosinophilic-fasciitis-like fibrosing lesions (panel 3) showing the 'groove sign'; head erythema with scaling in a patient with late acute/chronic overlap disease (panel 4); lichen-planus-like changes (panel 5) and pityriasis-rosea-like manifestations in 2 patients more than 6 months after HSCT (panel 6); distinctive dyspigmentation of the head with features of poikiloderma resembling xeroderma pigmentosum (panel 7); classical mucosal lesions with lichen-type features, hyperkeratotic plaques and atrophy on the buccal mucosa, tongue and genital area (panels 8-11); longitudinal ridging, splitting and pterygium formation of nails (panels 12,13) and examples of patchy scarring (panel 14) and nonscarring (panel 15) alopecia in 2 patients after recovery from chemoradiotherapy; hallmark histological changes with superficial sclerosis and vessel rarification (panels 16), classical lichenoid-type changes (panel 17) and changes of late acute/chronic overlap disease with interface dermatitis partly of the vacuolar and lichenoid type (panel 18). mal stem cells, are thought to reside [78]. However, while gene expression analysis in mouse models indicates that these cytokeratin-15-positive epidermal cells are early targets in GVHD, it is unclear whether this is the case in humans $[40,79,80]$.

Histologically, there is a stereotypical evolution of morphological findings of subtle endothelitis and perivascular mast cell degranulation in the uppermost dermis that are suggestive of but not specific for the disease. These changes are usually followed by the vacuolization of the basal epithelial layer (grade 1), keratinocyte apoptosis and satellitosis (grade 2), up to subepidermal clefting (grade 3) and epidermal separation (grade 4). Involvement of the upper portion of eccrine or follicular structures is a distinctive finding that often occurs early in the course of the disease and can prove helpful for diagnosis. Immunohistochemistry can identify the predominance of CD8+ lymphocytes as main effectors but its value in the diagnosis of acute GVHD is rather limited [81]. On a microscopic level, there is considerable overlap of histological findings of early GVHD and various other posttransplantation diseases (e.g. viral exanthems, eruptions due to immune reconstitution, drug reactions), overall decreasing the sensitivity and specificity of a skin biopsy in a given patient. Therefore, as there are no pathognomonic histological features for GVHD, the value of a biopsy lies mainly in lending support to the clinical diagnosis of GVHD or exclusion of other diseases, depending on the clinical context. Importantly, the number of lymphocytes entering the epidermis and quantity of apoptotic keratinocytes did not prove useful as predictor of the severity of the clinical disease, in contrast to the predictive value of substantial increases in total bilirubin, diarrhea and extent of rash and overall clinical GVHD grade for potentially fatal outcome [82, 83]. Furthermore, skin biopsies of a rather unspecific rash that occurs in the early phase after transplantation have been shown to be of limited value in predicting the progression from rash (viral-induced, drug-induced or early acute GVHD) to overt acute GVHD grade 2-4 irrespective of the stem cell source (peripheral blood, bone marrow). Likewise, the histopathological assessment of normal skin before allogeneic HSCT could not predict the development of GVHD $[81,84]$. So far, in patients with clinicopathological acute GVHD, there are no known morphological or immunohistochemical features predicting the risk of subsequent chronic GVHD. Only in the setting of nonmyeloablative conditioning a small retrospective study found that histologically 'proven' clinical acute GVHD with morphological features of both acute and chronic disease ('com- 
Table 5. Histological criteria for GVHD of skin and oral mucosa (adapted from Shulman et al. [21])

\begin{tabular}{lll}
\hline Organ/lesion & Minimal criteria for active GVHD & Specific criteria for chronic GVHD \\
\hline Skin, any stage & $\begin{array}{l}\text { Apoptosis in epidermal basal or lower malphigian } \\
\text { layer or outer root sheath of hair follicle or } \\
\text { acrosyringium } \pm \text { lichenoid inflammation } \pm \\
\text { vacuolar change } \pm \text { lymphocytic satellitosis }\end{array}$ & \\
\hline $\begin{array}{l}\text { Lichen-planus- } \\
\text { like }\end{array}$ & $\begin{array}{l}\text { Combination of epidermal orthokeratosis, hypergranulosis } \\
\text { and acanthosis with lichenoid changes } \pm \text { syringitis of eccrine } \\
\text { units } \pm \text { panniculitis }\end{array}$ \\
\hline Sclerotic & $\begin{array}{l}\text { Collagenous deposition with thickening throughout the } \\
\text { papillary dermis or pan-dermal collagenosis } \pm \text { panniculitis }\end{array}$ \\
\hline Morpheic & $\begin{array}{l}\text { Sclerosis in the lower reticular dermis or along the dermal- } \\
\text { hypodermal border } \pm \text { epidermal and adnexal involvement }\end{array}$ \\
\hline Fasciitis & $\begin{array}{l}\text { Lymphocytic infiltration of mucosa with variable } \\
\text { tion } \pm \text { panniculitis }\end{array}$ & \\
\hline Oral mucosa & & \\
\hline
\end{tabular}

posite' histological features) may predict the subsequent development of chronic GVHD [85]. In daily routine, the best way to provide an accurate diagnosis of acute GVHD may encompass a combined approach that includes mucocutaneous assessment, histopathological evaluation and exclusion of other diseases in the hands of experienced physicians and that sometimes requires repeat evaluations for an adequate diagnosis.

The histopathology of chronic GVHD has traditionally been divided into an epidermal (lichen-planus-like) and a dermal (sclerodermoid) type (fig. 4). Subtle histological features that are mainly regarded as hallmark changes in acute GVHD, e.g. satellitosis and vacuolization of the basal layer, may also be found in both chronic types, but are far more predominant in the epidermal type, as is adnexal involvement, e.g. cytotoxic acrosyringitis or folliculitis. However, spongiotic alterations may be found, and marked thickening of the stratum corneum, stratum granulosum and stratum spinosum together with a band-like infiltrate and perifollicular fibrosis are indicative features of lichen-planus-like chronic GVHD, whereas thickening, homogenization and compaction of the collagen bundles are hallmark findings in the sclerodermoid type.

The NIH Pathology working group has recommended to confirm clinically suspected chronic GVHD by histology; however, the role of subsequent biopsies to assess the response to treatment has not yet been determined [21].
The group emphasized that histological interpretation requires the consideration of the clinical context to minimize false-negative and false-positive diagnoses (e.g. drug reactions, concurrent infections or inflammatory reactions unrelated to GVHD). The proposed histological criteria for skin and oral mucosa now differentiate between minimal criteria for active disease and specific criteria for chronic GVHD (table 5) and, together with clinical, laboratory and radiographic information, are an integral part to yield 4 diagnostic categories, i.e. 'no GVHD', 'possible GVHD', 'consistent with GVHD' and 'definite GVHD'. Importantly, the diagnosis and staging committee recommended that keratinocyte apoptosis without other features of chronic GVHD found on day 80-100 screening skin biopsies does not indicate chronic GVHD and in that particular situation should not be taken to predict that alloreactive T-cell-induced flares may follow cessation of immunosuppressive therapy [20].

\section{New Classification Systems for GVHD}

Whereas the term acute GVHD has historically been used to describe a syndrome of dermatitis, cholestatic hepatitis and gastroenteritis that developed within the first 100 days after allogeneic HSCT, chronic GVHD has traditionally been used to describe a syndrome that occurred after day 100 and often contained features of auto- 
Table 6. Categories of acute and chronic GVHD (adapted from Filipovich et al. [20])

\begin{tabular}{|c|c|c|c|}
\hline Category & $\begin{array}{l}\text { Timing of symptoms } \\
\text { after HSCT or DLI }\end{array}$ & $\begin{array}{l}\text { Presence of acute } \\
\text { GVHD features }\end{array}$ & $\begin{array}{l}\text { Presence of chronic } \\
\text { GVHD features }\end{array}$ \\
\hline \multicolumn{4}{|l|}{ Acute GVHD } \\
\hline Classic & $\leq 100$ days & yes & no \\
\hline Persistent, recurrent or late onset & $>100$ days & yes & no \\
\hline \multicolumn{4}{|l|}{ Chronic GVHD } \\
\hline Classic & no time limit & no & yes \\
\hline Overlap syndrome & no time limit & yes & yes \\
\hline
\end{tabular}

immunity. This somewhat arbitrary time delineation was of high clinical value in the early era of myeloablative conditioning regimens in the setting of bone marrow or peripheral blood HSCT. Nowadays, in the era of increased numbers of haploidentical, cord blood, nonmyeloablative and unrelated transplants, so-called stem cell boosts and donor lymphocyte infusions, disease manifestations that were commonly observed in acute GVHD, can often develop after day 100 following transplantation, whereas, conversely, signs and symptoms of chronic GVHD may be present shortly after donor lymphocyte infusion. This paradigm shift is respected in the new categories of acute and chronic GVHD that were proposed by the recent NIH consensus conference and are outlined in figure 1 and table 6 [20]. Moreover, the distinction between limited and extensive chronic GVHD [86] that was introduced in 1980 on the basis of a retrospective observational study of only 20 patients is now proposed to be displaced by an organ scoring system (table 7). This proposed global scoring system reflects the clinical effects of chronic GVHD on the patient's functional status and finally classifies patients as having mild, moderate or severe chronic GVHD [20,86]. In the absence of clinical or histological features suggestive of chronic GVHD, the new onset, persistence and recurrence of characteristic manifestations of acute GVHD should now be considered as acute GVHD regardless of the time after transplantation [20]. The lack of standardized criteria for quantitative measurement of therapeutic response in clinical trials remained a major problem and obstacle for the efficient development and introduction of new agents in this disease [23]. The proposed organ scoring and response criteria address this issue at least in part, but it remains to be demonstrated in the future whether the course of the disease and the influence of drugs can be more precisely recorded.

Cutaneous Graft-versus-Host Disease

\section{Basic Preventive and Therapeutic Approaches to (Cutaneous) GVHD}

Two fundamentally different approaches for the prevention of GVHD have been established: immunosuppression with cyclophilin inhibitors such as cyclosporine or FK506 with or without methotrexate or T cell depletion. Both approaches have their specific advantages and disadvantages. Cyclophilin inhibitors interfere with the activation and expansion of donor $\mathrm{T}$ cells and are very effective in the prevention of GVHD but need to be taken over a long period of time and are associated with significant side effects, such as nephrotoxicity. In contrast to standard transplantation, ex vivo graft manipulation such as $T$ cell depletion has lower organ toxicity but is associated with higher incidences of graft failure or graft rejection, delayed immune reconstitution particularly of the CD4+ lymphocytes, decreased functional recovery of $\mathrm{T}$ cells and, importantly, impaired recovery of $\mathrm{T}$ cell repertoire diversity. While increased incidences of bacterial or fungal infections have not been documented, there is an enhanced risk of posttransplantation lymphoproliferative disease and leukemia relapse after transplantation of manipulated compared to unmanipulated stem cells, and the probability of reactivated viral infections such as cytomegalovirus appears to be increased $[87,88]$. Newer preventive strategies including cytokine-based approaches, e.g. antithymocyte globulin, anti-TNF- $\alpha$ antibody (infliximab), anti-TNF- $\alpha$ receptor (etanercept) or antiIL-2 receptor antibody (dacalizumab) to neutralize the conditioning-induced cytokines of the afferent phase of acute GVHD before infusion of the graft, are not yet firmly established in clinical use and may have a predominant role in the treatment of steroid-refractory disease [88]. Other immunosuppressive drugs such as mycophe-

Dermatology 2008;216:287-304 
Table 7. Organ scoring and global assessment and severity of chronic GVHD as proposed by the 2005 NIH Consensus Development Project (adapted from Schaffer [34])

\begin{tabular}{|c|c|c|c|}
\hline & Score 1 & Score 2 & Score 3 \\
\hline Skin & $\begin{array}{l}<18 \% \text { of BSA and no sclerotic } \\
\text { features }\end{array}$ & $\begin{array}{l}19-50 \% \text { of BSA or superficial sclerosis } \\
\text { (able to pinch) }\end{array}$ & $\begin{array}{l}>50 \% \text { of BSA or deep sclerosis } \\
\text { (unable to pinch) or impaired mo- } \\
\text { bility, ulceration or severe pruritus }\end{array}$ \\
\hline Mouth & $\begin{array}{l}\text { Mild signs/symptoms not limiting } \\
\text { oral intake }\end{array}$ & $\begin{array}{l}\text { Moderate signs/symptoms with partial } \\
\text { limitation of oral intake }\end{array}$ & $\begin{array}{l}\text { Severe signs/symptoms with major } \\
\text { limitation of oral intake }\end{array}$ \\
\hline Eyes & $\begin{array}{l}\text { Mild dry-eye symptoms (using eye- } \\
\text { drops } \leq 3 \times / \text { day) or asymptomatic } \\
\text { but signs of keratokonjunctivitis sicca }\end{array}$ & $\begin{array}{l}\text { Moderate dry-eye symptoms partially } \\
\text { affecting ADL (using eyedrops } \geq 3 \times / \text { day } \\
\text { or punctuate plugs), no visual impairment }\end{array}$ & $\begin{array}{l}\text { Severe dry-eye symptoms signifi- } \\
\text { cantly affecting ADL or unable to } \\
\text { work or loss of vision }\end{array}$ \\
\hline GI tract & $\begin{array}{l}\text { Symptoms without significant weight } \\
\text { loss }\end{array}$ & Symptoms with weight loss of $5-15 \%$ & $\begin{array}{l}\text { Symptoms with weight loss }>15 \% \text {, } \\
\text { requiring nutritional supplemen- } \\
\text { tation or need for esophageal } \\
\text { dilatation }\end{array}$ \\
\hline Liver & $\begin{array}{l}\text { Bilirubin, AP, AST or ALAT } \\
<2 \times \text { of normal upper limit }\end{array}$ & $\begin{array}{l}\text { All } 2-5 \times \text { of normal upper limit or } \\
\text { bilirubin }>3 \mathrm{mg} / \mathrm{dl}\end{array}$ & All $\geq 5 \times$ of upper normal limit \\
\hline Lungs $^{1}$ & $\begin{array}{l}\text { Mild symptoms (SOB after } 1 \text { flight } \\
\text { of steps); } \text { FEV }_{1} 60-79 \% \text { or LFS } 2\end{array}$ & $\begin{array}{l}\text { Moderate symptoms (SOB after walking } \\
\text { on flat ground); } \mathrm{FEV}_{1} 40-59 \% \text { or LFS 6-9 }\end{array}$ & $\begin{array}{l}\text { Severe symptoms }(\mathrm{SOB} \text { at rest } \\
\left.\text { or requiring supplement } \mathrm{O}_{2}\right) \\
\mathrm{FEV}_{1} \leq 39 \text { or LFS } 10-12\end{array}$ \\
\hline Joint/fascia & $\begin{array}{l}\text { Mild tightness of arms or legs, } \\
\text { mildly decreased ROM and not } \\
\text { affecting ADL }\end{array}$ & $\begin{array}{l}\text { At least } 1 \text { of the following: tightness of } \\
\text { arms or legs, joint contractures, erythema } \\
\text { due to fasciitis, moderately decreased ROM } \\
\text { and mild-moderate limitation of ADL }\end{array}$ & $\begin{array}{l}\text { Contractures with significantly } \\
\text { decreased ROM and significant } \\
\text { limitation of ADL }\end{array}$ \\
\hline Genital tract & $\begin{array}{l}\text { Mild signs/symptoms and no effect } \\
\text { on coitus/minimal discomfort on } \\
\text { examination }\end{array}$ & $\begin{array}{l}\text { Moderate signs/symptoms and mild } \\
\text { dyspareunia/discomfort with examination }\end{array}$ & $\begin{array}{l}\text { Advanced signs (strictures, labial } \\
\text { fusion or severe ulceration) and } \\
\text { severe pain with coitus/inability } \\
\text { to insert vaginal speculum }\end{array}$ \\
\hline $\begin{array}{l}\text { Global assess- } \\
\text { ment of chronic } \\
\text { GVHD }\end{array}$ & $\begin{array}{l}\text { Mild } \\
1-2 \text { organs (except the lung) with } \\
\text { a maximum organ score each of } 1\end{array}$ & $\begin{array}{l}\text { Moderate } \\
\geq 1 \text { site with an organ score of } 2 \text { or } \geq 3 \text { sites } \\
\text { with an organ score of } 1 \text { or lung score of } 1\end{array}$ & $\begin{array}{l}\text { Severe } \\
\text { Any organ score of } 3 \text { or lung score } \\
\text { of } 2\end{array}$ \\
\hline
\end{tabular}

$\mathrm{ADL}=$ Activities of daily living; ALAT = alanine aminotransferase; AP = alkaline phosphatase; AST = aspartate aminotransferase;

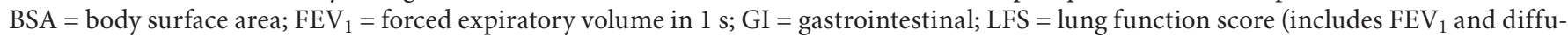
sion capacity of the lung for $\mathrm{CO}$ ); $\mathrm{ROM}=$ range of motion; $\mathrm{SOB}=$ shortness of breath.

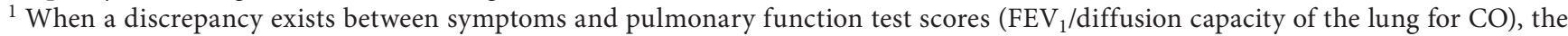
higher score should be used.

nolate mofetil as prophylactic treatments alone or in combination with established drugs are under active investigation but have not yet been proven to be effective [28].

The first-line treatment of significant acute ( $\geq$ grade II) or chronic GVHD consists of high doses of systemic corticosteroids $[46,54]$. The standard therapy of acute cutaneous GVHD below $50 \%$ of body surface involvement (<grade II) includes topical application of potent corticosteroids or tacrolimus [89]; by comparison, their application in chronic GVHD in addition to systemic therapy, especially at mucosal sites, is not established. Unfortunately, there is still no effective treatment for corticosteroid-refractory acute GVHD. A variety of agents has been investigated and will be tested in future, including chemical immunosuppressants such as mycophenolate mofetil, sirolimus or thalidomide, broad antilymphocyte antibodies (antithymocyte globulin, anti-CD3 such as OKT3 and visilizumab) and more specific agents directed against activation or adhesion molecules (anti- 
CD25, anti-IL-2 receptor, anti-CD147, anti-CD52) or cytokines such as anti-TNF- $\alpha$ antibody (infliximab) [26, 50, 54, 62, 88, 90, 91]. Extracorporeal photopheresis has been successfully applied in chronic GVHD, particularly in cutaneous GVHD, and will need to be tested as firstline treatment of specific subgroups in steroid-refractory GVHD [92]. Furthermore, other light sources such as psoralen preparations and direct exposure to UVA have been proven to be effective in some patients with isolated cutaneous GVHD [93]. Standard treatment of chronic GVHD includes cyclosporine and prednisone. Treatment regimens combining prednisone with cyclosporine or tacrolimus with mycophenolate mofetil are under current investigation. Other approaches including anti-TNF- $\alpha$ and anti-CD2 0 antibodies, pentostatin and sirolimus are currently studied as well [39]. Supportive care, accurate anti-infective treatment, balanced nutrition and topical emollients for the skin, mucous membranes and eyes are established in patients with both acute and chronic GVHD [89]. Furthermore, there are early reports indicating some efficacy of mesenchymal stem cells in steroidrefractory severe acute GVHD. Whether these beneficial effects will persist over time in these patients and whether they have a role in the treatment of chronic GVHD needs to be shown $[94,95]$.

\section{Outlook}

Allogeneic HSCT will remain a therapeutic cornerstone for an increasing number of diseases, with currently over 12,000 transplantations performed worldwide per year, and estimates of ongoing annual growth rates of $10-20 \%$ [96]. Global research goals to enhance treatment outcome and QOL of those patients incorporates extensive laboratory and clinical investigations, in particular to decrease the toxicity of conditioning regimens, advance donor-recipient typing and graft tolerance, reduce graft rejection, decrease GVHD and increase the graft- versus-tumor (GVT) effect in the setting of malignancy. In particular, research activity in the field of biomarkers, pathobiology, response criteria and therapy are key areas that will be of critical importance to encounter the increasing significance of chronic GVHD [22, 97]. Based on its multiorgan involvement with its features of both allo- and autoimmunity (or 'altered immunity'), chronic GVHD will require a multidisciplinary approach that importantly includes the dermatologists. Similarly, a sitespecific long-term management of active disease and sequelae will require the collaboration of various specialists, not only physicians, but also non-physician medical workers such as physiotherapists, psychologists and social workers. Effective coordination of information between patient, physicians and therapists will be facilitated by a simple and precise organizational and administrative algorithm. Despite these challenges, improvement of QOL and survival, which are both influenced by the occurrence and severity of chronic GVHD, remain the primary aims for patients after HSCT $[38,98]$. Unfortunately, we are not yet capable of separating T-cell-mediated harmful GVHD and beneficial GVT effects: as a result, graft manipulation such as T cell depletion not only abolishes the undesirable GVHD, but also minimizes beneficial GVT effects in the setting of malignancy. Missing alloreactive immunocompetent $\mathrm{T}$ cells thus increase the risk for disease relapse as well as severe infections at least during the first few years after transplantation. Therefore some degree of clinical chronic GVHD is currently embraced to decrease the chance for disease relapse accepting some decrease in QOL, rather than totally eliminating GVHD [38, 98, 99]. The ultimate goal is to find the optimal risk-benefit compromise and to accept mild chronic GVHD while maintaining the best possible QOL. Current and future investigations to enhance the GVT effect while decreasing GVHD will be ultimate to decrease tumor relapse and GVHD while enhancing survival and provide allogeneic HSCT to a broader patient collective.

\section{References}

1 Thomas ED: A history of haemopoietic cell transplantation. Br J Haematol 1999; 105: 330-339.

$>2$ Lorenz E, Congdon CC, Uphoff D: Modification of acute irradiation injury in mice and guinea-pigs by bone marrow injections. $\mathrm{Ra}-$ diology 1952;58:863-877.

Cutaneous Graft-versus-Host Disease $\checkmark 3$ Congdon CC, Uphoff D, Lorenz E: Modification of acute irradiation injury in mice and guinea-pigs by injection of bone marrow: a histopathologic study. J Natl Cancer Inst 1952;13:73-107.

$>4$ Jacobson LO, Simmons EL, Marks EK, Eldredge $\mathrm{JH}$ : Recovery from irradiation injury. Science 1951;113:510-511.
5 Jacobson LO, Simmons EL, Marks EK, Gaston EO, Robson MJ, Eldredge JH: Further studies on recovery from radiation injury. J Lab Clin Med 1951;37:683-697.

-6 Ford CE, Hamerton JL, Barnes DWH, Loutit JF: Cytological identification of radiationchimaeras. Nature 1956;177:452-454. 
7 Thomas ED, Lochte HL, Cannon JH: Supralethal whole body irradiation and isologous marrow transplantation in man. J Clin Invest 1959;38:1709-1716.

>8 Mathé G, Amiel JL, Schwarzenberg L, Catton A, Schneider M: Adoptive immunotherapy of acute leukemia: experimental and clinical results. Cancer Res 1965;25:15251531.

>9 Gatti RA, Meuwissen HJ, Allen HD, Hong R, Good RA: Immunological reconstitution of sex-linked lymphopenic immunological deficiency. Lancet 1968;ii:1366-1369.

10 Appelbaum FR: The use of bone marrow and peripheral blood stem cell transplantation in the treatment of cancer. CA Cancer J Clin 1996;46:142-164.

-11 Copelan EA: Hematopoietic stem-cell transplantation. N Engl J Med 2006;354:18131826.

12 Slatter MA, Gennery AR: Umbilical cord stem cell transplantation for primary immunodeficiencies. Expert Opin Biol Ther 2006; 6:555-565.

13 Barkholt L, Bregni M, Remberger M, Blaise D, Peccatori J, Massenkeil G, Pedrazzoli P, Zambelli A, Bay JO, François S, Martino R, Bengala C, Brune M, Lenhoff S, Porcellini A, Falda M, Siena S, Demirer T, Niederwieser D, Ringden O: Allogeneic haematopoietic stem cell transplantation for metastatic renal carcinoma in Europe. Ann Oncol 2006;17: 1134-1140.

-14 Gratwohl A, Baldomero H, Horisberger B, Schmid C, Passweg J, Urbano-Ispizua A: Current trends in hematopoietic stem cell transplantation in Europe. Blood 2002;100: 2374-2386.

15 Gratwohl A: New developments in hematopoietic stem cell transplantation. Ther Umsch 2002;59:571-576.

16 Sullivan KM: Graft-versus-host disease; in Forman SJ, Blume KG, Thomas ED (eds): Bone Marrow Transplantation. Cambridge, Blackwell Scientific, 1994, pp 339-362.

-17 Storek J, Gooley T, Witherspoon RP, Sullivan KM, Storb R: Infectious morbidity in longterm survivors of allogeneic marrow transplantation is associated with low CD4 T cell counts. Am J Hematol 1997;54:131-138.

-18 Welniak LA, Blazar BR, Murphy WJ: Immunobiology of allogeneic hematopoietic stem cell transplantation. Annu Rev Immunol 2007;25:139-170.

-19 Hymes SR, Turner ML, Champlin RE, Couriel DR: Cutaneous manifestations of chronic graft-versus-host disease. Biol Blood Marrow Transplant 2006;12:1101-1113.

-20 Filipovich AH, Weisdorf D, Pavletic S, Socie G, Wingard JR, Lee SJ, Martin P, Chien J, Przepiorka D, Couriel D, Cowen EW, Dinndorf P, Farrell A, Hartzman R, HensleeDowney J, Jacobsohn D, McDonald G, Mittleman B, Rizzo JD, Robinson M, Schubert M, Schultz K, Shulman H, Turner M, Vogelsang G, Flowers ME: National institutes of health consensus development project on criteria for clinical trials in chronic graftversus-host disease. I. Diagnosis and staging working group report. Biol Blood Marrow Transplant 2005;11:945-956.

21 Shulman HM, Kleiner D, Lee SJ, Morton T, Pavletic SZ, Farmer E, Moresi JM, Greenson J, Janin A, Martin PJ, McDonald G, Flowers ME, Turner M, Atkinson J, Lefkowitch J, Washington MK, Prieto VG, Kim SK, Argenyi Z, Diwan AH, Rashid A, Hiatt K, Couriel D, Schultz K, Hymes S, Vogelsang GB: Histopathologic diagnosis of chronic graftversus-host disease: National Institutes of Health consensus development project on criteria for clinical trials in chronic graftversus-host disease. II. Pathology working group report. Biol Blood Marrow Transplant 2006;12:31-47.

22 Schultz KR, Miklos DB, Fowler D, Cooke K, Shizuru J, Zorn E, Holler E, Ferrara J, Shulman H, Lee SJ, Martin P, Filipovich AH, Flowers ME, Weisdorf D, Couriel D, Lachenbruch PA, Mittleman B, Vogelsang GB, Pavletic SZ: Toward biomarkers for chronic graft-versus-host disease: National Institutes of Health consensus development project on criteria for clinical trials in chronic graft-versus-host disease. III. Biomarker working group report. Biol Blood Marrow Transplant 2006;12:126-137.

23 Pavletic SZ, Martin P, Lee SJ, Mitchell S, Jacobsohn D, Cowen EW, Turner ML, Akpek G, Gilman A, McDonald G, Schubert M, Berger A, Bross P, Chien JW, Couriel D, Dunn JP, Fall-Dickson J, Farrell A, Flowers ME, Greinix H, Hirschfeld S, Gerber L, Kim S, Knobler R, Lachenbruch PA, Miller FW, Mittleman B, Papadopoulos E, Parsons SK, Przepiorka D, Robinson M, Ward M, Reeve B, Rider LG, Shulman H, Schultz KR, Weisdorf D, Vogelsang GB: Measuring therapeutic response in chronic graft-versus-host disease: National Institutes of Health consensus development project on criteria for clinical trials in chronic graft-versus-host disease. IV. Response criteria working group report. Biol Blood Marrow Transplant 2006;12:252266.

24 Couriel D, Carpenter PA, Cutler C, BolanosMeade J, Treister NS, Gea-Banacloche J, Shaughnessy P, Hymes S, Kim S, Wayne AS, Chien JW, Neumann J, Mitchell S, Syrjala K, Moravec CK, Abramovitz L, Liebermann J, Berger A, Gerber L, Schubert M, Filipovich AH, Weisdorf D, Schubert MM, Shulman H, Schultz K, Mittelman B, Pavletic S, Vogelsang GB, Martin PJ, Lee SJ, Flowers ME: Ancillary therapy and supportive care of chronic graft-versus-host disease: National Institutes of Health consensus development project on criteria for clinical trials in chronic graft-versus-host disease. V. Ancillary therapy and supportive care working group report. Biol Blood Marrow Transplant 2006; 12:375-396.

25 Martin PJ, Weisdorf D, Przepiorka D, Hirschfeld S, Farrell A, Rizzo JD, Foley R,
Socie G, Carter S, Couriel D, Schultz KR, Flowers ME, Filipovich AH, Saliba R, Vogelsang GB, Pavletic SZ, Lee SJ: National Institutes of Health consensus development project on criteria for clinical trials in chronic graft-versus-host disease. VI. Design of clinical trials working group report. Biol Blood Marrow Transplant 2006;12:491-505.

26 Marshall SR: Technology insight: ECP for the treatment of GVHD - can we offer selective immune control without generalized immunosuppression? Nat Clin Pract Oncol 2006;3:302-314.

27 Perez-Simon JA, Sanchez-Abarca I, DiezCampelo M, Caballero D, San Miguel J: Chronic graft-versus-host disease: pathogenesis and clinical management. Drugs 2006;66:1041-1057.

28 Bolanos-Meade J: Update on the management of acute graft-versus-host disease. Curr Opin Oncol 2006;18:120-125.

29 Billingham RE: Reactions of grafts against their hosts. Science 1959;130:947-953.

30 Billingham RE: The biology of graft versus host reactions. Harvey Lec 1966-1967;62:2178.

31 Korngold R, Sprent J: T cell subsets in graft versus host disease; in Deeg HJ, Ferrara J, Atkinson J (eds): Graft-versus-Host Disease: Immunobiology, Pathophysiology, and Treatment. New York, Dekker, 1990, pp 3150.

32 Krensky AM, Weiss A, Crabtree G, Davis MM, Parham P: T-lymphocyte-antigen interactions in transplant rejection. N Engl J Med 1990;322:510-517.

33 Mielcarek M, Martin PJ, Leisenring W, Flowers ME, Maloney DG, Sandmaier BM, Maris $\mathrm{MB}$, Storb R: Graft-versus-host disease after nonmyeloablative versus conventional hematopoietic stem cell transplantation. Blood 2003;102:756-762.

34 Schaffer JV: The changing face of graft-versus-host disease. Semin Cutan Med Surg 2006;25:190-200.

35 Deeg HJ, Spitzer TR, Cottler-Fox M, Cahill R, Pickle LW: Conditioning-related toxicity and acute graft-versus-host disease in patients given methotrexate/cyclosporine prophylaxis. Bone Marrow Transplant 1991;7: 193-198.

36 Weisdorf DJ: Chronic graft-versus-host disease: where is promise for the future? Leukemia 2005; 19:1532-1535.

37 Fraser CJ, Bhatia S, Ness K, Carter A, Francisco L, Arora M, Parker P, Forman S, Weisdorf D, Gurney JG, Baker KS: Impact of chronic graft-versus-host disease on the health status of hematopoietic cell transplantation survivors: a report from the bone marrow transplant survivor study. Blood 2006; 108:2867-2873.

38 Lee SJ, Kim HT, Ho VT, Cutler C, Alyea EP, Soiffer RJ, Antin JH: Quality of life associated with acute and chronic graft-versushost disease. Bone Marrow Transplant 2006; 38:305-310. 
39 Akpek G, Akpek CS, Vogelsang G: Clinical spectrum and therapeutic approaches to chronic graft-vs-host disease; in Ferrara J, Cooke K, Deeg HJ (eds): Graft-versus-Host Disease. New York, Dekker, 2005, pp 555608.

40 Zhan Q, Signoretti S, Whitaker-Menezes D, Friedman TM, Korngold R, Murphy GF: Cytokeratin-15-positive basal epithelial cells targeted in graft-versus-host disease express a constitutive antiapoptotic phenotype. J Invest Dermatol 2007;127:106-115.

41 Zhou L, Askew D, Wu C, Gilliam AC: Cutaneous gene expression by DNA microarray in murine sclerodermatous graft-versushost disease, a model for human scleroderma. J Invest Dermatol 2007;127:281-292.

42 Ferrara JLM, Cooke KR, Teshima T: The pathophysiology of graft-versus-host disease; in Ferrara JLM, Cooke KR, Deeg H) (eds): Graft-versus-Host Disease. New York, Dekker, 2005, pp 1-34.

-43 Hofmeister CC, Quinn A, Cooke KR, Stiff P, Nickoloff B, Ferrara JL: Graft-versus-host disease of the skin: life and death on the epidermal edge. Biol Blood Marrow Transplant 2004;10:366-372.

-44 Hermanns-Le T, Paquet P, Piérard-Franchimont C, Arrese JE, Piérard GE: Regulatory function of factor-XIIIa-positive dendrocytes in incipient toxic epidermal necrolysis and graft-versus-host reaction: a hypothesis. Dermatology 1999;198:184-186.

-45 Yoo YH, Park BS, Whitaker-Menezes D, Korngold R, Murphy GF: Dermal dendrocytes participate in the cellular pathology of experimental acute graft-versus-host disease. J Cutan Pathol 1998;25:426-434.

-46 Couriel D, Caldera H, Champlin R, Komanduri K: Acute graft-versus-host disease: pathophysiology, clinical manifestations, and management. Cancer 2004;101:1936-1946.

47 Dickinson AM, Wang XN, Sviland L, VythDreese FA, Jackson GH, Schumacher TN, Haanen JB, Mutis T, Goulmy E: In situ dissection of the graft-versus-host activities of cytotoxic $\mathrm{T}$ cells specific for minor histocompatibility antigens. Nat Med 2002;8 410-414.

-48 Gratwohl A, Hermans J, Niederwieser D, van Biezen A, van Houwelingen HC, Apperley J: Female donors influence transplant-related mortality and relapse incidence in male recipients of sibling blood and marrow transplants. Hematol J 2001;2:363-370.

49 Hess AD: Modulation of graft-versus-host disease: role of regulatory $\mathrm{T}$ lymphocytes. Biol Blood Marrow Transplant 2006;12:1321.

50 Cutler C, Antin JH: Chronic graft-versushost disease. Curr Opin Oncol 2006;18:126131.

51 Sullivan KM: Graft-versus-host disease; in Blume KG, Forman SJ, Appelbaum FR (eds): Thomas' Hematopoietic Cell Transplantation, ed 3. Malden, Blackwell Publishing, 2004, pp 635-664.
52 Lawley TJ, Peck GL, Moutsopoulos HM, Gratwohl AA, Deisseroth AB: Scleroderma, Sjögren-like syndrome, and chronic graftversus-host disease. Ann Intern Med 1977; 87:707-709.

53 Gratwhol AA, Moutsopoulos HM, Chused TM, Akizuki M, Wolf RO, Sweet JB, Deisseroth AB: Sjögren-type syndrome after allogeneic bone-marrow transplantation. Ann Intern Med 1977;87:703-706.

54 Higman MA, Vogelsang GB: Chronic graft versus host disease. Br J Haematol 2004;125: 435-454.

55 Daneshpouy M, Socie G, Lemann M, Rivet J, Gluckman E, Janin A: Activated eosinophils in upper gastrointestinal tract of patients with graft-versus-host disease. Blood 2002; 99:3033-3040.

56 Jacobsohn DA, Schechter T, Seshadri R, Thormann K, Duerst R, Kletzel M: Eosinophilia correlates with the presence or development of chronic graft-versus-host disease in children. Transplantation 2004;77:10961100.

57 Biedermann BC, Sahner S, Gregor M, Tsakiris DA, Jeanneret C, Pober JS, Gratwohl A: Endothelial injury mediated by cytotoxic T lymphocytes and loss of microvessels in chronic graft versus host disease. Lancet 2002;359:2078-2083.

58 Baroni SS, Santillo M, Bevilacqua F, Luchetti M, Spadoni T, Mancini M, Fraticelli P, Sambo P, Funaro A, Kazlauskas A, Avvedimento EV, Gabrielli A: Stimulatory autoantibodies to the PDGF receptor in systemic sclerosis. N Engl J Med 2006;354:26672676.

59 Zorn E: CD4+CD25+ regulatory $\mathrm{T}$ cells in human hematopoietic cell transplantation. Semin Cancer Biol 2006;16:150-159.

60 Miura Y, Thoburn CJ, Bright EC, Phelps ML, Shin T, Matsui EC, Matsui WH, Arai S, Fuchs EJ, Vogelsang GB, Jones RJ, Hess AD: Association of FOXP3 regulatory gene expression with graft-versus-host disease. Blood 2004;104:2187-2193.

61 Zorn E, Kim HT, Lee SJ, Floyd BH, Litsa D, Arumugarajah S, Bellucci R, Alyea EP, Antin JH, Soiffer RJ, Ritz J: Reduced frequency of FOXP3+ CD4+CD25+ regulatory $\mathrm{T}$ cells in patients with chronic graft-versus-host disease. Blood 2005;106:2903-2911.

62 Cutler C, Miklos D, Kim HT, Treister N, Woo SB, Bienfang D, Klickstein LB, Levin J, Miller K, Reynolds C, Macdonell R, Pasek M, Lee SJ, Ho V, Soiffer R, Antin JH, Ritz J, Alyea E: Rituximab for steroid-refractory chronic graft-versus-host disease. Blood 2006; 108:756-762.

63 Rowe V, Banovic T, MacDonald KP, Kuns R, Don AL, Morris ES, Burman AC, Bofinger HM, Clouston AD, Hill GR: Host B cells produce IL-10 following TBI and attenuate acute GVHD after allogeneic bone marrow transplantation. Blood 2006;108:2485-2492.
4 Rappeport J, Mihm M, Reinherz E, Lopansri S, Parkman R: Acute graft-versus-host disease in recipients of bone-marrow transplants from identical twin donors. Lancet 1979;2:717-720.

65 Hess AD: The immunobiology of syngeneic/ autologous graft-versus-host disease; in Ferrara JLM, Deeg HJ, Burakoff SJ (eds): Graftversus-Host Disease, ed 2. New York, Dekker, 1997, pp 561-586.

66 Saurat JH: Cutaneous manifestations of graft-versus-host disease. Int J Dermatol 1981;20:249-256.

67 Itin PH, Lautenschlager S, Orth B, Rufli T, Gratwohl A: Skin manifestations of graftversus-host reaction following bone marrow transplantation. Schweiz Med Wochenschr 1996;126:339-347.

68 Johnson ML, Farmer ER: Graft-versus-host reactions in dermatology. J Am Acad Dermatol 1998;38:369-392, quiz 393-396.

69 Aractingi S, Chosidow O: Cutaneous graftversus-host disease. Arch Dermatol 1998; 134:602-612

70 Antin JA, Deeg HJ: Clinical spectrum of acute graft-vs-host disease; in Ferrara JL, Cooke KR, Deeg HJ (eds): Graft-versus-Host Disease. New York, Dekker, 2005, pp $369-$ 381.

71 Przepiorka D, Weisdorf D, Martin P, Klingemann HG, Beatty P, Hows J, Thomas ED: 1994 consensus conference on acute GVHD grading. Bone Marrow Transplant 1995;15: 825-828.

72 Baselga E, Drolet BA, Segura AD, Leonardi CL, Esterly NB: Dermatomal lichenoid chronic graft-versus-host disease following varicella-zoster infection despite absence of viral genome. J Cutan Pathol 1996;23:576581.

73 Schaffer JV, McNiff JM, Seropian S, Cooper DL, Bolognia JL: Lichen sclerosus and eosinophilic fasciitis as manifestations of chronic graft-versus-host disease: expanding the sclerodermoid spectrum. J Am Acad Dermatol 2005;53:591-601.

74 Spiryda LB, Laufer MR, Soiffer RJ, Antin JA: Graft-versus-host disease of the vulva and/or vagina: diagnosis and treatment. Biol Blood Marrow Transplant 2003;9:760-765.

75 Nagler R, Marmary Y, Krausz Y, Chisin R, Markitziu A, Nagler A: Major salivary gland dysfunction in human acute and chronic graft-versus-host disease (GVHD). Bone Marrow Transplant 1996;17:219-224.

76 Biedermann BC, Tsakiris DA, Gregor M, Pober JS, Gratwohl A: Combining altered levels of effector transcripts in circulating $\mathrm{T}$ cells with a marker of endothelial injury is specific for active graft-versus-host disease. Bone Marrow Transplant 2003;32:1077-1084.

77 Lerner KG, Kao GF, Storb R, Buckner CD, Clift RA, Thomas ED: Histopathology of graft-versus-host reaction (GVHR) in human recipients of marrow from HL-Amatched sibling donors. Transplant Proc 1974;6:367-371. 
78 Sale GE, Shulman HM, Gallucci BB, Thomas ED: Young rete ridge keratinocytes are preferred targets in cutaneous graft-versus-host disease. Am J Pathol 1985;118:278-287.

-79 Whitaker-Menezes D, Jones SC, Friedman TM, Korngold R, Murphy GF: An epithelial target site in experimental graft-versus-host disease and cytokine-mediated cytotoxicity is defined by cytokeratin 15 expression. Biol Blood Marrow Transplant 2003;9:559-570.

-80 Lyle S, Christofidou-Solomidou M, Liu Y, Elder DE, Albelda S, Cotsarelis G: The c8/144b monoclonal antibody recognizes cytokeratin 15 and defines the location of human hair follicle stem cells. J Cell Sci 1998;111:31793188.

-81 Heldal D, Brinch L, Evensen SA, Tjonnfjord GE, Aamodt G, Elgjo K, Sviland L: Skin biopsies for early diagnosis and prognosis of graft-versus-host disease in recipients of allogeneic stem cells from blood or bone marrow. Bone Marrow Transplant 2004;34:345350.

82 Darmstadt GL, Donnenberg AD, Vogelsang GB, Farmer ER, Horn TD: Clinical, laboratory, and histopathologic indicators of the development of progressive acute graft-versus-host disease. J Invest Dermatol 1992;99: 397-402.

83 Zhou Y, Barnett MJ, Rivers JK: Clinical significance of skin biopsies in the diagnosis and management of graft-versus-host disease in early postallogeneic bone marrow transplantation. Arch Dermatol 2000;136: 717-721.

-84 KohlerS, Hendrickson MR, Chao NJ, Smoller BR: Value of skin biopsies in assessing prognosis and progression of acute graft-versushost disease. Am J Surg Pathol 1997;21:988996.
85 Bridge AT, Nelson RP Jr, Schwartz JE, Mirowski GW, Billings SD: Histological evaluation of acute mucocutaneous graftversus-host disease in nonmyeloablative hematologic stem cell transplants with an observation predicting an increased risk of progression to chronic graft-versus-host disease. Am J Dermatopathol 2007;29:1-6.

86 Shulman HM, Sullivan KM, Weiden PL, McDonald GB, Striker GE, Sale GE, Hackman R, Tsoi MS, Storb R, Thomas ED: Chronic graft-versus-host syndrome in man: a long-term clinicopathologic study of $20 \mathrm{Se}$ attle patients. Am J Med 1980;69:204-217.

87 Soiffer R: Graft manipulation to prevent graft-vs-host disease; in Ferrara JLM, Cooke KR, Deeg HJ (eds): Graft-versus-Host Disease, ed 3. New York, Dekker, 2005, pp 481509.

88 Chao NJ, Holler E, Deeg HJ: Prophylaxis and treatment of acute graft-versus-host disease; in Ferrara JLM, Cooke KR, Deeg HJ (eds): Graft-versus-Host Disease, ed 3. New York, Dekker, 2005, pp 459-479.

89 Penas PF, Fernandez-Herrera J, Garcia-Diez A: Dermatologic treatment of cutaneous graft versus host disease. Am J Clin Dermatol 2004;5:403-416.

90 Giaccone L, Martin P, Carpenter P, Moravec C, Hooper H, Funke VA, Storb R, Flowers ME: Safety and potential efficacy of low-dose methotrexate for treatment of chronic graftversus-host disease. Bone Marrow Transplant 2005;36:337-341.

-91 Wetzig T, Sticherling M, Simon JC, Hegenbart U, Niederwieser D, Al-Ali HK: Medium dose long-wavelength ultraviolet a (UVA1) phototherapy for the treatment of acute and chronic graft-versus-host disease of the skin. Bone Marrow Transplant 2005;35:515-519.

92 Dall'Amico R, Messina C: Extracorporeal photochemotherapy for the treatment of graft-versus-host disease. Ther Apher 2002; 6:296-304.
3 Bonanomi S, Balduzzi A, Tagliabue A, Biagi E, Rovelli A, Corti P, Crippa D, Uderzo C: Bath PUVA therapy in pediatric patients with drug-resistant cutaneous graft-versushost disease. Bone Marrow Transplant 2001; 28:631-632.

94 Le Blanc K, Rasmusson I, Sundberg B, Gotherstrom C, Hassan M, Uzunel M, Ringden $\mathrm{O}$ : Treatment of severe acute graft-versushost disease with third party haploidentical mesenchymal stem cells. Lancet 2004;363: 1439-1441.

95 Ringden O, Uzunel M, Rasmusson I, Remberger M, Sundberg B, Lonnies H, Marschall HU, Dlugosz A, Szakos A, Hassan Z, Omazic B, Aschan J, Barkholt L, Le Blanc K: Mesenchymal stem cells for treatment of therapyresistant graft-versus-host disease. Transplantation 2006;81:1390-1397.

96 Horowitz MM: Uses and growth of hematopoietic cell transplantation; in Thomas ED, Blume KG, Forman S (eds): Hematopoietic Cell Transplantation. Cambridge, Blackwell Science, 1999, pp 12-18.

97 Shlomchik WD, Lee SJ, Couriel D, Pavletic SZ: Transplantation's greatest challenges: advances in chronic graft-versus-host disease. Biol Blood Marrow Transplant 2007; 13(suppl 1):2-10.

98 Lee SJ, Klein JP, Barrett AJ, Ringden O, Antin JH, Cahn JY, Carabasi MH, Gale RP, Giralt S, Hale GA, Ilhan O, McCarthy PL, Socie G, Verdonck LF, Weisdorf DJ, Horowitz MM: Severity of chronic graft-versus-host disease: association with treatment-related mortality and relapse. Blood 2002;100:406414.

99 Andorsky DJ, Loberiza FR, Lee SJ: Pre-transplantation physical and mental functioning is strongly associated with self-reported recovery from stem cell transplantation. Bone Marrow Transplant 2006;37:889-895. 